\title{
(+)-N-(2-Hydroxypropyl)lindcarpine: A New Cytotoxic Aporphine Isolated from Actinodaphne pruinosa Nees
}

Tiah Rachmatiah ${ }^{1,2}$, Mat Ropi Mukhtar ${ }^{3}$, Mohd Azlan Nafiah ${ }^{4}$, Muhammad Hanafi ${ }^{5}$, Soleh Kosela ${ }^{2}$, Hiroshi Morita ${ }^{6}$, Marc Litaudon ${ }^{7}$, Khalijah Awang ${ }^{3}$, Hanita Omar ${ }^{3}$ and A. Hamid A. Hadi ${ }^{3}$ \%

1 Department of Chemistry, Faculty of Science and Mathematic, University of Indonesia, Depok, Indonesia; E-mail: tiahrachmatiah@yahoo.com (T.R.)

2 Department of Pharmacy, Faculty of Science and Mathematic, National Institute of Science and Technology, Jakarta, Indonesia

3 Centre for Natural Products and Drug Discovery, Block D, Department of Chemistry, Faculty of Science, University of Malaya, 50603 Kuala Lumpur, Malaysia; E-mails: matropi@um.edu.my (M.R.M.), khalijah@um.edu.my (K.A.)

4 Chemistry Department, Faculty of Science and Technology, University of Pendidikan Sultan Idris, Tg. Malim, Perak, Malaysia; E-mail: azlan@upsi.edu.my (M.A.N.)

5 Research Center for Chemistry, Indonesian Institute of Sciences, Bandung, Indonesia

6 Faculty of Pharmaceutical Sciences, Hoshi University, Ebara 2-4-41 Shinagawa, Tokyo 142-8501, Japan; E-mail: moritah@hoshi.ac.jp (H.M.)

7 Institut de Chimie des Substances Naturelles, Centre Nationale de la Recherche Scientifique, UPR2301, 91198, Gif-sur-Yvette, Cedex, France; E-mail: marc.litaudon@icsn.cnrs-gif.fr (M.L.)

* Author to whom correspondence should be addressed; E-mail: ahamid@um.edu.my; Tel.: +603-79674010; Fax: 603-79674193

Received: 30 June 2009; in revised form: 22 July 2009 /Accepted: 27 July 2009 / Published: 31 July 2009

Abstract: One new alkaloid; (+)- $N$-(2-hydroxypropyl)lindcarpine (1), together with four known aporphine alkaloids, $(+)$-boldine (2) (+)-norboldine (3), (+)-lindcarpine (4) and (+)methyllindcarpine (5) were isolated from the stem bark of Actinodaphne pruinosa Nees (Lauraceae). (+)- $N$-(2-Hydroxypropyl)lindcarpine (1) exhibited cytotoxic activity against P-388 murine leukemia cells with an $\mathrm{IC}_{50}$ value of $3.9 \mu \mathrm{g} / \mathrm{mL}$. Structural elucidation of all 
the compounds were performed by spectral methods such as 1D- and 2D- NMR, IR, UV, and HRESIMS.

Keywords: Actinodaphne pruinosa; Lauraceae; aporphine alkaloid; cytotoxic

\section{Introduction}

Actinodaphne pruinosa is a tree of moderate size (about 30-40 feet) found in Peninsular Malaysia and Jawa, Indonesia. Locally, Actinodapne is known as wuru (Indonesia) or medang kuning and medang kunyit (Malaysia) [1-2]. Actinodaphne plants of the family Lauraceae have been reported to produce isoquinoline alkaloids (aporphines, oxoaporphines) and lactones [3-4]. These alkaloids are of some pharmacological importance, as exemplified by liriodenine, an oxoaporphine, which was reported to have antitumor, antibacterial, and antifungal activities [5]. In addition, dicentrine, an aporphine, was known to have cytotoxic activity against P-388 murine cells [6]. In the present paper, the isolation and characterization of new aporphine; (+)- $N-(2$-hydroxypropyl)lindcarpine (1) is described. This alkaloid, together with four known alkaloids, $(+)$-boldine (2) [7], (+)-norboldine (3) [7], (+)-lindcarpine (4) [7,8] and (+)-methyllindcarpine (5) [8], were obtained from a $\mathrm{CH}_{2} \mathrm{Cl}_{2}$ extract of the stem bark of Actinodaphne pruinosa.

Figure 1. Alkaloids 1- 5 isolated from Actinodaphne pruinosa.

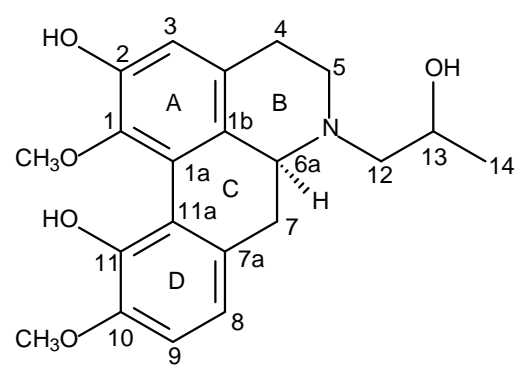

(1)<smiles>COc1cc2c(cc1O)C[C@H]1NCCc3cc(O)c(OC)c-2c31</smiles>

(3)<smiles>COc1cc2c(cc1O)C[C@H]1c3c(cc(O)c(O)c3-2)CCN1C</smiles>

(2)<smiles>COc1ccc2c(c1O)-c1c(OC)c(O)cc3c1[C@@H](C2)NCC3</smiles>

(4)<smiles>COc1ccc2c(c1O)-c1c(O)c(O)cc3c1[C@@H](C2)N(C)CC3</smiles>

(5) 


\section{Results and Discussion}

(+)- $N$-(2-Hydroxypropyl)lindcarpine (1; see Figure 1) exhibited a molecular formula of $\mathrm{C}_{21} \mathrm{H}_{26} \mathrm{NO}_{5}$ based on the HRESIMS spectrum (positive mode) which showed a pseudomolecular ion at $\mathrm{m} / \mathrm{z}$ 372.1797 $[\mathrm{M}+\mathrm{H}]^{+}$(calcd. 372.1811, $\Delta-1.4 \mathrm{mmu}$ ). The IR spectrum revealed an absorption band at $3,180 \mathrm{~cm}^{-1}$ due to the $\mathrm{OH}$ stretching vibration. The overall physical properties and NMR spectral profile revealed its identity as a member of the aporphine group of isoquinoline, a characteristic and distinguishable chemical marker of Actinodaphne plants [3,4].

In the ${ }^{1} \mathrm{H}-\mathrm{NMR}$ spectrum (Table 1 ) the presence of a methyl group attached to $-\mathrm{CH}(\mathrm{OH})$ - signal at $\delta$ $1.22(3 \mathrm{H}, d, J=6.1 \mathrm{~Hz})$; two methoxyl signals at $\delta 3.65$ and $\delta 3.92$; three aromatic protons at $\delta 6.79$ $(s, \mathrm{H}-3), \delta 6.84(d, 8.0 \mathrm{~Hz}, \mathrm{H}-8)$ and $\delta 6.86(d, 8.0 \mathrm{~Hz}, \mathrm{H}-9)$ were observed. The ${ }^{13} \mathrm{C}-\mathrm{NMR}$ (Table 1) and DEPT spectra, showed a total of 21 carbon signals; three methyls, four methylenes, one methine bearing hydroxyl group, four methines, and nine quaternary carbons in which four are aromatic oxygenated carbon signals.

Table 1. ${ }^{1} \mathrm{H}-\mathrm{NMR}(400 \mathrm{MHz})$ and ${ }^{13} \mathrm{C}-\mathrm{NMR}(100 \mathrm{MHz})$ spectral data of compound 1 in $\mathrm{CDCl}_{3}$ ( $\delta$ in ppm, $J$ in $\mathrm{Hz}$ ).

\begin{tabular}{|c|c|c|c|}
\hline Position & $\delta{ }^{1} \mathbf{H}(\mathrm{Hz})$ & $\delta^{13} \mathrm{C}$ & HMBC $\left({ }^{2} J,{ }^{3} J\right)$ \\
\hline 1 & & 140.6 & \\
\hline $1 \mathrm{a}$ & & 125.0 & \\
\hline $1 b$ & & 131.2 & \\
\hline 2 & & 147.6 & \\
\hline 3 & $6.79 s$ & 114.0 & $1,2,3 \mathrm{a}, 4$ \\
\hline $3 a$ & & 129.2 & \\
\hline \multirow[t]{2}{*}{4} & $2.67 \mathrm{~m}$ & 29.1 & \\
\hline & $2.71 \mathrm{~m}$ & & $1 b$ \\
\hline 5 & $3.08 \mathrm{~m}$ & 52.3 & $12,6 a$ \\
\hline $6 a$ & $3.30 d d(13.1,3.2)$ & 61.9 & 12 \\
\hline \multirow[t]{2}{*}{7} & $2.90 d d(13.1,3.2)$ & 36.7 & $6 a$ \\
\hline & $2.56 t(13.1)$ & & \\
\hline $7 \mathrm{a}$ & & 129.9 & \\
\hline 8 & $6.84 d(8.0)$ & 119.5 & $7,11 \mathrm{a}, 10$ \\
\hline 9 & $6.86 d(8.0$ & 111.4 & $7 \mathrm{a}, 11$ \\
\hline 10 & & 149.2 & \\
\hline 11 & & 143.2 & \\
\hline $11 \mathrm{a}$ & & 119.6 & \\
\hline \multirow[t]{2}{*}{12} & $2.80 \mathrm{~m}$ & 63.3 & $5,6 \mathrm{a}$ \\
\hline & $\begin{array}{c}2.38 d d \\
(13.7,9.0)\end{array}$ & & 5,13 \\
\hline 13 & $3.89 \mathrm{~m}$ & 66.1 & \\
\hline $14(\mathrm{Me})$ & $1.22 d(6.1)$ & 20.8 & 13 \\
\hline 1-OMe & $3.65 s$ & 62.4 & 1 \\
\hline $10-\mathrm{OMe}$ & $3.92 s$ & 56.4 & 10 \\
\hline
\end{tabular}


The complete ${ }^{1} \mathrm{H}$ - and ${ }^{13} \mathrm{C}$-NMR (Figure 2) spectral assignment of $\mathbf{1}$ was accomplished by thorough analysis of DEPT, COSY (Figure 3), HMQC (Figure 4), and HMBC data. The ${ }^{1} \mathrm{H}-{ }^{1} \mathrm{H}$ COSY, combined with the HMQC spectrum revealed that $\mathbf{1}$ has the following partial structure: $-\mathrm{CH}_{2} \mathrm{CH}_{2}$ (C4 and $\mathrm{C} 5)$; $-\mathrm{CHCH}_{2}-(\mathrm{C} 6 \mathrm{a}-\mathrm{C} 7)$; $=\mathrm{CHCH}=(\mathrm{C} 8-\mathrm{C} 9)$; $-\mathrm{CH}_{2} \mathrm{CH}-(\mathrm{C} 12-\mathrm{C} 13)$; and $-\mathrm{CHCH}_{3}-(\mathrm{C} 13-\mathrm{C} 14)$. All of these segments were compatible for rings $\mathrm{B}, \mathrm{C}$, and $\mathrm{D}$ of a 1,2,9,10-tetrasubstituted aporphine type linked to $-\mathrm{CH}_{2} \mathrm{CH}(\mathrm{OH}) \mathrm{CH}_{3}$ unit. The $\mathrm{HMBC}$ spectrum of $\mathbf{1}$ provided conclusive evidence for the presence of the 2-hydroxypropyl chain unit. The HMBC spectrum showed cross peaks of H-3 with $\mathrm{C} 1, \mathrm{C} 2, \mathrm{C} 3 \mathrm{a}$ and $\mathrm{C} 4$; H-12 with $\mathrm{C} 5, \mathrm{C} 6 \mathrm{a}$ and $\mathrm{C} 14$; H-8 with $\mathrm{C} 7, \mathrm{C} 11 \mathrm{a}$ and C-10; and H-9 with the C7a and $\mathrm{C} 11$.

Figure 2. ${ }^{13} \mathrm{C}-\mathrm{NMR}$ spectrum of alkaloid 1.

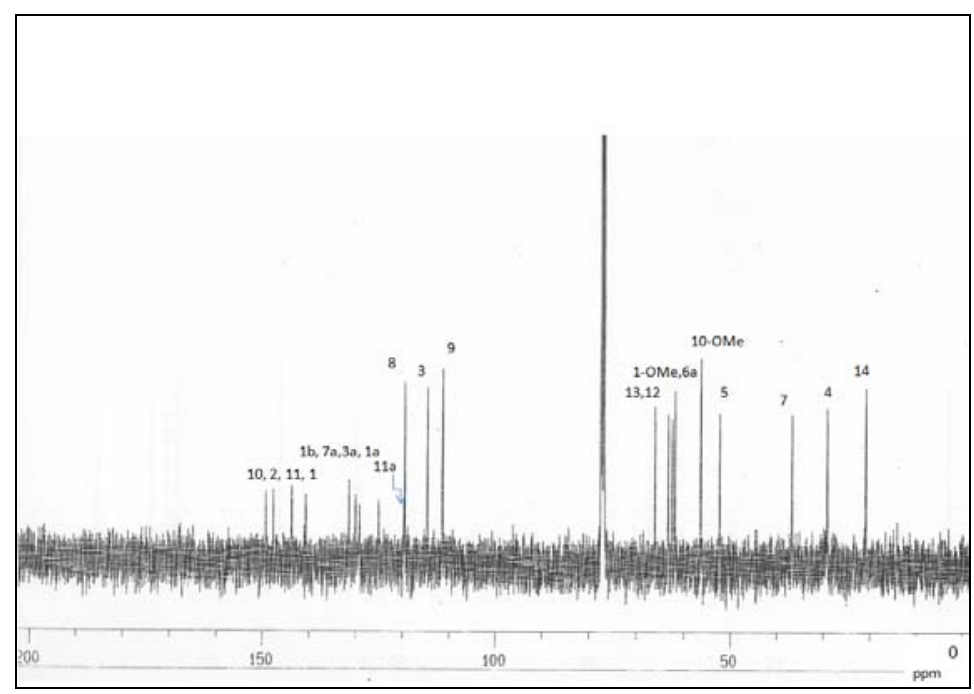

Figure 3. COSY spectrum of alkaloid 1.

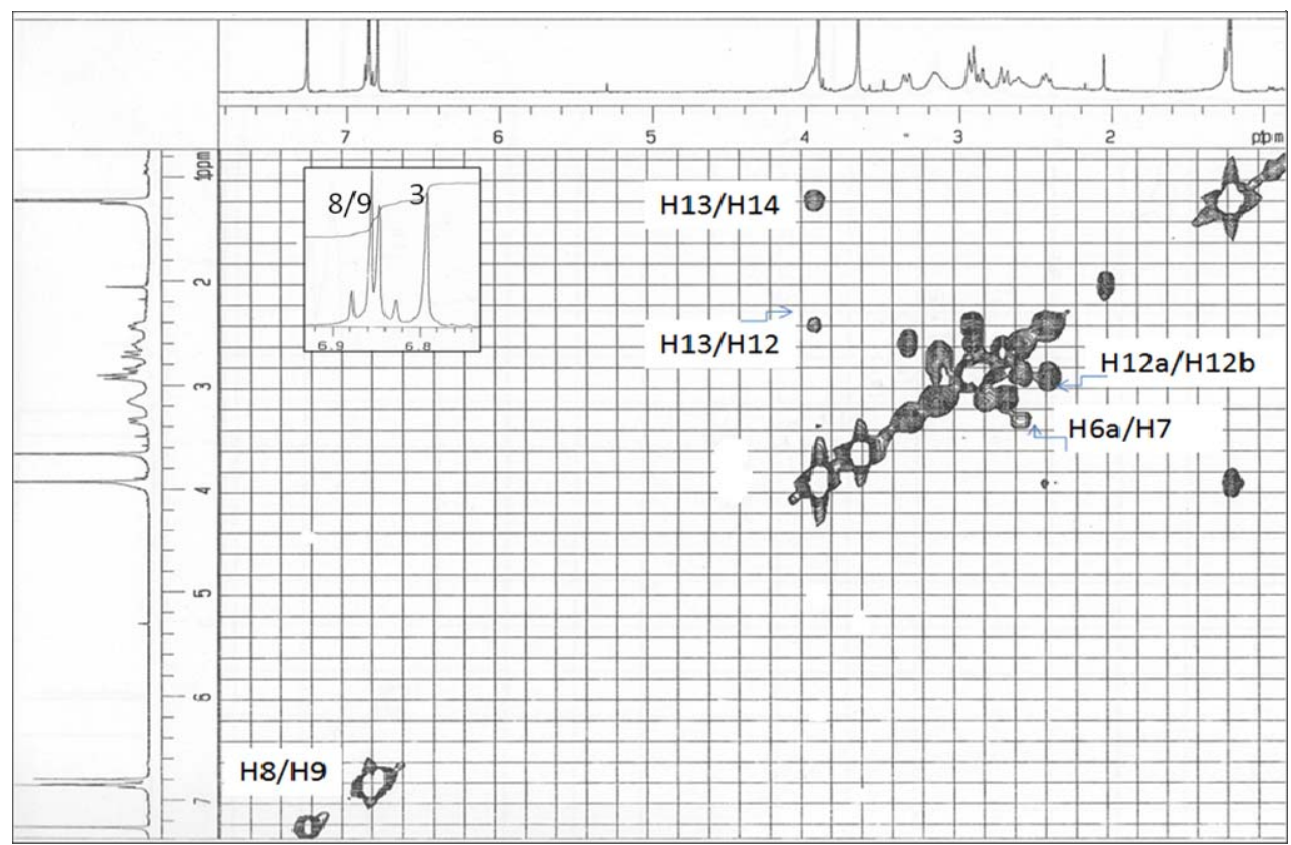


Figure 4. HMQC spectrum of alkaloid 1.

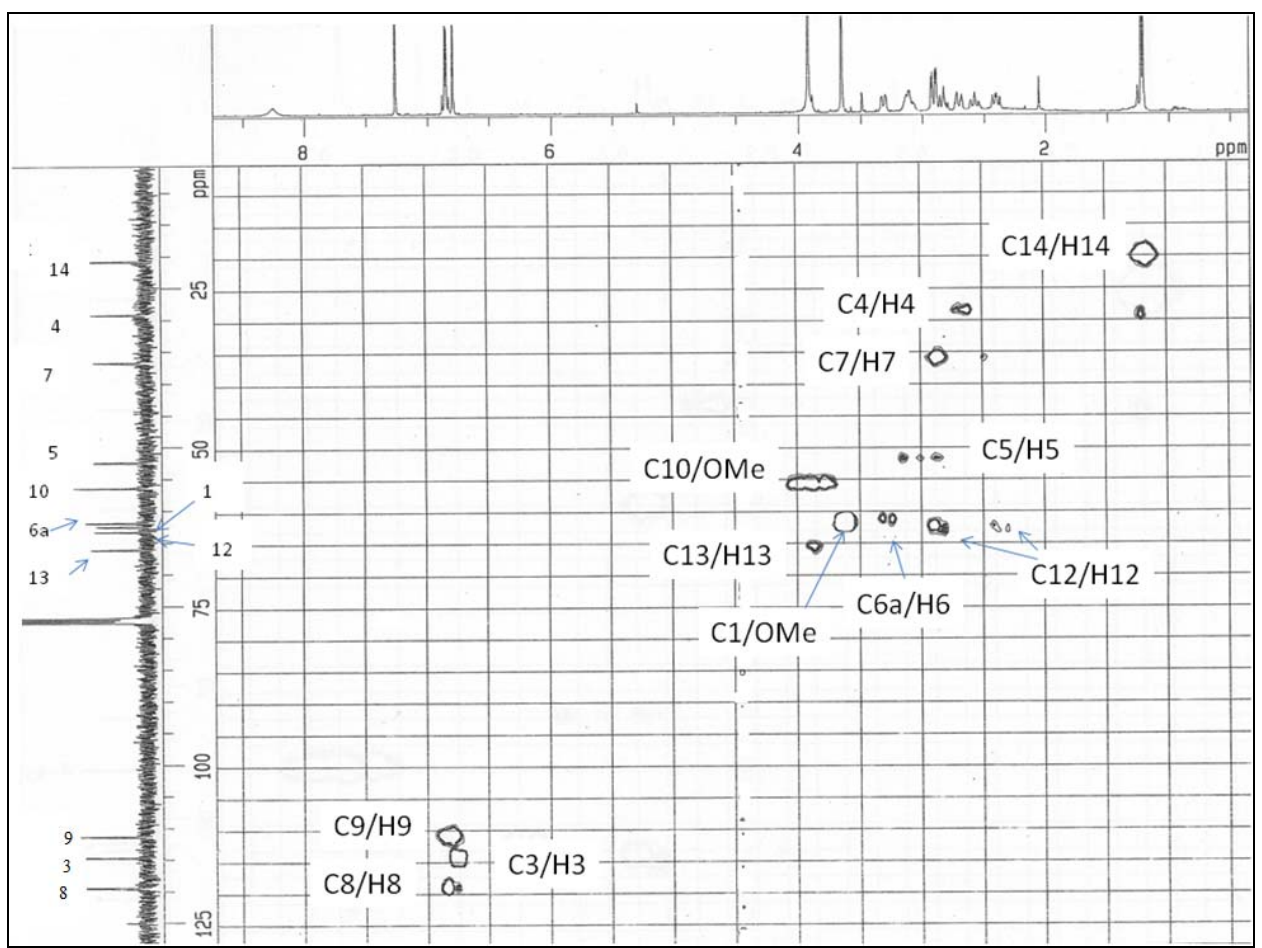

The NOE differential measurements, showed enhancement of H-4 ( $\delta$ 2.67) upon radiation of H-3 $(\delta$ 6.79). In addition the irradiation of $\mathrm{H}-9$ showed enhancement of $10-\mathrm{OMe}$ protons and $\mathrm{H}-8$, suggesting that the methoxyl groups are placed at $\mathrm{C}-1$ and $\mathrm{C}-10$, respectively. The absolute configuration of the asymmetric carbon at $\mathrm{C}-13$ was not determined due to the limited amount of compound available, so alkaloid 1 can be considered a racemic mixture.

To our knowledge, there has been no report on the phytochemical study and medicinal value of Actinodaphne pruinosa. This is the first report on the occurrence of $N$-(2-hydroxypropyl)aporphine type of alkaloid; (+)- $N$-(2-hydroxypropyl)lindcarpine (1) which exhibited significant cytotoxicity against P-388 murine leukemia cells.

\section{Conclusions}

In summary, we have observed that Actinodaphne pruinosa produces alkaloids closely related to those found in A. nitida, A. acutivena, A. abovata and A. sesquipedalis which were studied previously $[4,9,10]$. These species yielded noraporphine or $N$-methylaporphine types. The presence of $N$ - $(2-$ hydroxypropyl)aporphine type which significantly exhibited a potent cytotoxicity against P-388 [11] murine leukemia cells with $\mathrm{IC}_{50} 3.9 \mu \mathrm{g} / \mathrm{mL}$, suggesting its potential for further investigation as anticancer agent.

\section{Experimental}

\section{General}

The optical rotations were recorded on s Jasco (Japan) P1010 instrument equipped with a tungsten lamp. HRESIMS was obtained on a Thermo Finnigan Automass Multi. The ultraviolet spectra were 
obtained in $\mathrm{MeOH}$ on a Shimadzu UV-160A ultraviolet-visible spectrometer. The infrared spectra were recorded on a Perkin Elmer 1600 Double-Beam recording spectrometer, using chloroform as solvent. The ${ }^{1} \mathrm{H}-\mathrm{NMR}$ and ${ }^{13} \mathrm{C}-\mathrm{NMR}$ spectra were recorded in deuterated chloroform on a JEOL 400 MHz. Chemical shifts are reported in ppm on $\delta$ scale, and the coupling constants are given in Hz. Silica gel 60, 70-230 mesh ASTM (Merck 7734) and silica gel 60, 230-400 Mesh ASTM (Merck 9385) were used for column and flash chromatography, respectively. Mayer's reagent was used for alkaloid screening.

\section{Plant material}

Stem bark of Actinodaphne pruinosa, collected at Bukit Bauk, Dungun, Terengganu, Malaysia, in May 2004 was identified by Mr. Teo Leong Eng. A voucher specimen (KL 5055) was deposited in the Herbarium of Department of Chemistry, University of Malaya, Malaysia and at the Herbarium of the Forest Research Institute, Kepong, Malaysia.

\section{Extraction and isolation of the alkaloids}

The dried stem bark of Actinodaphne pruinosa $(2.0 \mathrm{~kg})$ was ground and extracted exhaustively for 12 hours by Soxhlet extraction with hexane, followed by $\mathrm{CH}_{2} \mathrm{Cl}_{2}$. Extraction of alkaloids was carried out in the usual manner, which has been described in detail [12,13] and gave $43.0 \mathrm{~g}$ of crude alkaloid. The crude alkaloid was submitted to exhaustive column chromatography over silica gel using $\mathrm{CH}_{2} \mathrm{Cl}_{2}$ gradually enriched with methanol to yield 26 fractions. Fractions were combined on the basis of TLC behavior. Fractions 24-25 (3.0 g), afforded three alkaloids identified as (+)- $N$-(2-hydroxypropyl)lindcarpine (1) (0.21\%, PTLC; $\mathrm{CH}_{2} \mathrm{Cl}_{2}-\mathrm{MeOH}$ 98:2), (+)-lindcarpine (4) (1.51\%, PTLC; $\mathrm{CH}_{2} \mathrm{Cl}_{2^{-}}$ $\mathrm{MeOH}$ 95:5), (+)-methyllindcarpine (5) (1.89\%, PTLC; $\mathrm{CH}_{2} \mathrm{Cl}_{2}-\mathrm{MeOH}$ 97:3). Fraction 19-20 (1.3 g) produced alkaloid 2, identified as (+)-boldine (1.58\%, PTLC; $\mathrm{CH}_{2} \mathrm{Cl}_{2}-\mathrm{MeOH}$ 95:5) [6]. (+)Norboldine (3, 1.89\%), was also separated by preparative TLC of fraction 26 (190 mg) over silica gel using $\mathrm{CH}_{2} \mathrm{Cl}_{2}-\mathrm{MeOH}$; 95:5: saturated with $\mathrm{NH}_{4} \mathrm{OH}$ ).

$(+)-N-(2-H y d r o x y p r o p y l) l i n d c a r p i n e \quad\left(1\right.$, Figure 1): A colorless powder,$[\alpha]_{D}^{25}=+120^{\circ}(c=0.02$, $\mathrm{MeOH}), \mathrm{UV}: \lambda_{\text {methanol: }} 309 \mathrm{~nm}$; IR $v_{\max }(\mathrm{KBr}): 3,180,3,014,2,934,2,360,1,594 \mathrm{~cm}^{-1}$; HRESIMS (positive mode): $m / z: 372.1797[\mathrm{M}+\mathrm{H}]^{+}$(Calcd. 372.1811, $\Delta-1.4 \mathrm{mmu}$ for $\left.\mathrm{C}_{21} \mathrm{H}_{26} \mathrm{NO}_{5}\right) ;{ }^{1} \mathrm{H}-\mathrm{NMR}(400$ $\left.\mathrm{MHz}, \mathrm{CDCl}_{3}\right)$ and ${ }^{13} \mathrm{C}-\mathrm{NMR}\left(100 \mathrm{MHz}, \mathrm{CDCl}_{3}\right)$ see Table 1; Principle NOE's (\%) in $\mathrm{CDCl}_{3}: \mathrm{OCH}_{3}-10$ to $\mathrm{H}-9(2.6 \%)$.

\section{Cytotoxic assays}

The cytotoxicity of (+)-N-(2-hydroxypropyl)lindcarpine (1) against P-388 murine leukemia cells was tested using MTT-microculture tetrazolim assay [11].

\section{Acknowledgements}

The authors thank the Malaysian Government through the vots: PPF/FP092/2005C, ScienceFund 12-02-03-2063 (UM) and the grant from Centre Nationale de la Recherche Scientifique (France). 


\section{References}

1. Burkill, I.H. A Dictionary of the Economic Products of the Malay Peninsula; Ministry of Agriculture Malaysia: Kuala Lumpur, Malaysia, 1935; pp. 42-43.

2. Ridley, H.N. The Flora of the Malay Peninsula; Reeve \& Co. Ltd.: London, UK, 1924; pp. 107-112.

3. Kim, M.R.; Jung, H.J.; Min, B.S.; Oh, S.R.; Kim, C.H.; Ahn, K.S.; Kang, W.S.; Lee, H.K. Constituents from the stems of Actinodaphne lancifolia. Phytochemistry 2002, 59, 861-865.

4. Uprety, H.; Bhakuni, D.S.; Dhar, M. M. Aporphine Alkaloids of Litsea Sebifera, L. Wightiana and Actinodaphne Obovata. Phytochemistry 1972, 11, 3057-3059.

5. Leboeuf, M.; Cavé, A.; Bhaumik, P.K.; Mukherjee, B.; Mukherjee, R. The Phytochemistry of the Annonaceae. Phytochemistry 1980, 21, 2783-2813.

6. Kittisak, L.; Angerhofer, C.K.; Chai, H.; Pezzuto, J.M.; Cordell, G.A.; Ruangrungsi, N. Cytotoxic and Antimalarial Alkaloids from the Tubers of Stephania pierrei. J. Nat. Prod. 1993, $56,1468-1478$.

7. Guinaudeau, H.; Leboeuf, M.; Cavé , A. Aporphine alkaloids. Lloydia 1975, 38, 275-288.

8. Shao, W.S.; Shoei, S.L.; Li, Y.C.; Chien, K.C. Separation Of Aporphine Alkaloids By Micellar Electrokinetic Chromatography. J. Chromatogr. A 1997, 767, 277-284.

9. Johns, S. R.; Lamberton, J. A.; Sioumis, A. A. Alkaloids of Actinodaphne nitida (Lauraceae). Aust. J. Chem. 1969, 22, 2257-2257.

10. Lu, S.T.; Wang, S.J.; Lin, F.S. Studies on the Alkaloids of Formosan Lauraceous Plants. XIV.: Alkaloids of Actinodaphne acutivena (Hayata) Nakai and Litsea hayatae. J. Pharm. Soc. Jap. 1969, 89, 1313-1317.

11. Alley, M.C.; Scudiero, D.A.; Monks, A.; Hursey, M. L.; Czerwinski, M. J.; Fine, D. L.; Abbott, B. J.; Mayo, J.G.; Shoemaker, R.H.; Boyd, M.R. Feasibility of Drug Screening with Panels of Human Tumor Cell Lines Using a Microculture Tetrazolium Assay. Cancer Res. 1988, 48, 589-610.

12. Mukhtar, M.R.; Martin, M.T.; Domansky, M.; Pais, M.; Hadi, A.H.A.; Awang, K. Phoebegrandines A and B, Proaporphine-Tryptamine Dimers, from Phoebe grandis. Phytochemistry 1997, 45, 1543-1546.

13. Mukhtar, M.R.; Hadi, A.H.A.; Sevenet, T.; Martin, MT.; Awang, K. Phoebegrandine C A Novel Proaporphine-Tryptamine Dimer from Phoebe grandis (Nees) Merr. Nat. Prod. Res. 2004, 18, 163-167.

Sample Availability: Samples of compounds 2-4 are available from the authors.

(C) 2009 by the authors; licensee Molecular Diversity Preservation International, Basel, Switzerland. This article is an open-access article distributed under the terms and conditions of the Creative Commons Attribution license (http://creativecommons.org/licenses/by/3.0/). 